\title{
Report of an Announced Dismissal ${ }^{*}$
}

It was the beginning of summer of 8 years ago, the sun was going down beyond the Alps, and I was coming back from work. At home, my kids and their mother were waiting for me, but I would have liked to be somewhere else.

I had recently turned 50, a life spent at growing up as a usual man, only child, brilliant student, degree in electrical engineering, I work in highly technical fields. Lifetime of common relationship with beautiful women, first (Catholic) marriage broken off a few years later without any children, then I met the one who would have become the mother of my children. A love story in which we believed with all our strength, three beautiful children that I loved and I still love.

But this straight man had a secret since he was 8: I felt, it was an unacceptable way of thinking for those times, to be something different, somebody else. I didn't understand why I wanted to be a girl but my body said something different, I felt odd and, at the same time, I didn't want to believe not to be like the others, also because like the other boys, I liked girls. I didn't know whom to ask for help: Catholic schools, an only child from a middle-class family: so I decided not to talk to anybody.

One day a sister was born: Annalisa and I was 10 at the time. I was happy not to be alone anymore, but after 2 months she died, she was born premature, and she couldn't absorb nutrition. From that moment on I felt a strong need to be someone else, but I couldn't tell anyone, and I decided to accept with all my strength the role that was given to me from society. Unfortunately, sometimes I had to hide this being and periodically refuse her, but like a buoy, it always floated to the surface. I also thought about sharing this secret with the two most important women in my life, but each one turned up at different times and soon I had to decide to clip my wings again.

In 2004, however, the marriage crisis provoked me a strong depression causing a hormonal decrease to childish level: when I was a child, I had cryptorchidism problems that had been treated with doses of hormones. It was happening again, surely due to depression: a doctor helped me, and he prescribed a testosterone therapy again. After a while, my male role returned normal, by then my wife didn't want to know anything about me anymore, and so I started having problems again, the only thing that wouldn't have caused significant family problems. I started to wear women's clothes again, secretly, and like Batgirl, I had a den where I could finally be my real self. I felt happy like that, I was feeling myself, but I had to hide. I started wishing to go out of the 'Batgirl-cave'. Thus, taking advantage of the company's crisis, in which I worked, and it was established the redundancy, I started careful outings among people. It amazed me how people around me didn't look at me; actually, sometimes men let me pass first: I started asking myself some questions. Nobody knew anything about me and also at work I had to be very careful to keep my real nature secret otherwise it would have provoked a great deal of stress. I started feeling that being always closer and closer to becoming a necessity. At work and at home I had to constrain myself, I didn't want to lose my children, but only during these moments I felt free, I felt myself. I was going crazy.

\footnotetext{
* The following self-narrative account was translated into English by Ilaria Abate.
} 
I started a couple therapy hoping to talk to my wife would have helped to control this side of me that was about to subdue me. The therapist, instead, was the cause of my wedding. My wife decided to leave me. I was losing control of myself. I was desperate.

So, that summer afternoon of 2009 I stopped the car, and I started staring at the sunset. I had to take a decision: kill myself forever and going on hiding and repress life source of continuous stress or trying to understand what was going on inside myself and maybe hoping to improve my life.

I couldn't repress that part of me; I've been doing this for way too long, I couldn't hide myself again. Thus, I decided to continue along that path that I didn't know where it would have led me.

I had to identify myself with a name that suited me: I gave myself the name of my dead sister; so Annalisa was born. I was 50 .

Now it was a matter of working on it.

I started to work on my mind to try to destroy with my "need" of what was left of my life: my children. I focused on how to conciliate these new circumstances with having three magnificent children that I loved. In the meantime, I kept on evolving and hiding what was emerging from my past; the more time passed away, the more I was aware of what my sensations were when I was a child and so my dysphoria to my real life. In fact, I couldn't stand my workplace anymore, where I started seeing generalized homo-transphobic attitudes. As a consequence, it was so important to say nothing about me above all until my children were ready to handle the pressure created by the news of my change. In fact, in my company worked parents whose children went to the same schools and they shared the same interests as mine. Therefore, with the managed life changed, I had to keep on looking for the right way of telling it to my children.

3 years later, during which I focused on my kids, promising each other a peace treaty so that the kids grew as quickly as possible before we finally separate. It was a conflict that barely killed me. It was very hard to handle the kids, the separation, my period of research about myself and the work that every day turned into something alien. During that period, my parents got sick and died quickly thereafter.

The time had come to sort out my jumbled life: I looked for psychological help, which was more appropriate for my path that was revealing more and more transitional. In fact, inside me, the need to free my real identity became unbearable: I found a center in Turin that was involved with people with Gender Identity Disorder.

The real transitional process had begun. I started the hormone replacement therapy. Soon it has been clear that it was impossible to bare everything: I separated, and I went to live on my own.

Finally, I was free to be myself.

It was the time during which I could have started living my female life, but I still had to act like a man, 'father' for my children and so I kept on being also a "business" man because it wasn't the right time to reveal my true identity.

During my free time, I could breathe, at work and with my children I still had to dress up forcefully like a man. 
My breasts started to develop; I had to hide it, I was scared that it could have been visible. It was hard to go to work putting myself in somebody else shoes that wasn't mine anymore: it was hard to concentrate while I was working, I often closed myself in the toilet and cried.

2014 was a very difficult year: stress was high. I was often depressed. I then stayed at home on sick leave. It was on that occasion that the company sent a medical check at home: it turned out I wasn't at home. To be true, during the medical check I was deeply asleep after taking medicine administrated from the psychiatrist of that time. I had to prove everything across psychiatrists' reports that were helping me, with the list of all the prescribed treatments and their effects and, at last, I received a fine anyway. In addition, having a second check-up at the end of the sick week, grew in me the feeling I was an unwelcomed guest. In fact, such incidents happened periodically, above all during periods of sickness, in the previous years.

In the same year, we also started the legal separation at the court. They attempted to attribute the separation as fault as well as supposing that my transgender condition was genetically transmissible and the court reached to the decision by a social worker and a psychologist to check my parenthood. In the end, they established that I was a good parent as well and so the court established that being transgender wouldn't nullify good parenthood. I started also paying the spousal support.

Can you imagine how this all dragged down my life?

2015 saw the beginning of the social welfare of my kids from a psychologist, which my wife and I found in the meanwhile.

The working situation got harder and harder: I was not feeling comfortable, I felt among enemies. In other words, hell. But destiny soon would have chosen for me. Towards May, the company gave me the fault together with another two people as the fault of the failure of a project to which a client claimed damages. The job was hard, and the only thing that I did was consulted a lawyer who showed me that the company had to notify the working problem when it happened, in autumn 2014 and not after 6 months in May 2015. With the lawyer's help, I replied to the charge punctually answering with suitable technical objections. Unfortunately, that was not enough, and after 3 days, they called me in the office where I was immediately fired by my company.

It didn't seem real: it was like being out of my body, and I was looking at the worst worker's nightmare. I told myself: "no, it is not happening to me!". I told him: "Do you realize that you are throwing away an entire family? Do you know these are one-paycheck families?".

They told me: "You can say whatever you want, we decided to fire you. Get out of the room".

I felt like sheer drop into hell.

They brought me to the desk and they put a guy to control that I wouldn't steal anything: they almost looked in my knickers while I was filling the box with the things that a worker collects on his own desk during 10 years of working life. In the end, they put me to the door. To the two work-mates who were summed in the notification and that received only 3 suspension's days, I asked to be brought to my car. When I put the boxes in the car, I burst into tears bringing out all the feminine desperation that I couldn't hold anymore.

It was May 2015. 
I was desperate, it took me three days to understand what had happened to me and at least one year to swallow what I'd been through. I challenged the being fired with the lawyer's help: as far as I suspected it, I couldn't prove the discrimination, there hadn't been apparent episodes. At the same time, I was even ready to make my situation visible across the media, but this would expose my children. They were still at the beginning of the social welfare program to my coming out that, in the meantime, it happened right in the spring of 2015: they were fragile. They wouldn't bear a pressure so strong and I didn't want to lose them.

So I gave up to destiny, hoping to solve the problem at work.

After a while, thinking about the last few working months, some incidence came to my mind that became suspicious. I remembered that during the coffee break at the vending machine, I came across the personal office's employees. I remembered that some of them looked at me from head to toe just like I came from outer space. Who knows maybe they noticed some changes in me? On the other side, I hide my breasts and I had less facial hair, and we know how much women are curious, above all if they work in the same office. Who knows if their gossip arrived to the head's ears and maybe, they wanted to fire me from a long time ago, they couldn't have got information about me. And maybe becoming aware of my path, knowing that after a coming out it would have been difficult to fire me because it would have been a discrimination, they hadn't built this all up to dismiss me? Maybe we'll never know this, but I will always have this doubt.

It was a devastating blow. After 30 years of working life, I found myself in the middle of a street with three children, a separation, my life, the cost for transition to put up with. Initially, I got from bed to couch, from couch to bed, I felt like a human garbage. I kept on going over what had happened to me and angriness raised. Every time I walked across the company, I felt bad and I got to the point of imagining to seek revenge on those people responsible for my dismissal. I also thought about ending this forever. These were very strong feeling to manage. Obviously, my children knew about my dismissal, official and unofficial motivation and they also saw resentment. Fortunately, their presence, their love had been my hub, the Pole Star to follow to go on. One day I was with my second child in a big bricolage center. While we were walking around the shelves, I saw from afar one of the bosses who took part in my dismissal. I turned tail and went pale as if I had seen a ghost, I reached my son and I told him what had just happened to me. I was scared to meet that person, if I had met him how I could have reacted, if I would have met him in front of me. Obviously, he couldn't have recognized me since I "changed a lot". Fortunately, I didn't meet him. But my son felt how I was feeling, in fact, the day after we talked about it and he told me that he was ready to jump over me and stop me to prevent any foolishness. That gave me the feeling of what was happening to me. It was necessary to work on it to avoid that the feeling of revenge devoured me. I started changing my perspective view my personal experience and I realized with a lot of effort to thinking that it could represent a possible better change. I soon understood that possibility was one thing, probability was something else. I realized that through time probabilities would play a prime role.

Today, after two and a half years away, I haven't overcome that blow, because I haven't found a job yet. I tried to reintegrate myself as an engineer but the required went a senior profile or something too professional until they highlighted the missing match between me and my male documents. I'm waiting for the court case for sex change. I'm trying to reintegrate in other 
professional fields looking for lower positions, maybe that can match with my female figure, since "...they don't know how to conciliate a woman engineer with male documents...".

I still believe that, quite apart from objective difficulties of looking for a job for an engineer with higher qualifications to the agency and aged 58, the biggest obstacle to overcome is fear and discrimination of transgender people. 